Research Article

\title{
Intrachromosomal karyotype asymmetry in Orchidaceae
}

\author{
Enoque Medeiros-Neto ${ }^{1}$, Felipe Nollet ${ }^{1}$, Ana Paula Moraes ${ }^{2,3}$ and Leonardo P. Felix ${ }^{1}$ \\ ${ }^{1}$ Departamento de Ciências Biológicas, Laboratório de Citogenética Vegetal, Centro de Ciências Agrárias, \\ Universidade Federal da Paraíba, Campus II, Areia, PB, Brazil. \\ ${ }^{2}$ Departamento de Genética, Instituto de Biociências, Universidade Estadual Paulista "Júlio de Mesquita \\ Filho", Botucatu, SP, Brazil. \\ ${ }^{3}$ Instituto de Ciências e Tecnologia, Universidade Federal de São Paulo, São José dos Campos, SP, Brazil.
}

\begin{abstract}
The asymmetry indexes have helped cytotaxonomists to interpret and classify plant karyotypes for species delimitation efforts. However, there is no consensus about the best method to calculate the intrachromosomal asymmetry. The present study aimed to compare different intrachromosomal asymmetry indexes in order to indicate which are more efficient for the estimation of asymmetry in different groups of orchids. Besides, we aimed to compare our results with the Orchidaceae phylogenetic proposal to test the hypothesis of Stebbins (1971). Through a literature review, karyotypes were selected and analyzed comparatively with ideal karyotypes in a cluster analysis. All karyotypes showed some level of interchromosomal asymmetry, ranging from slightly asymmetric to moderately asymmetric. The five tested intrachromosomal asymmetry indexes indicated Sarcoglottis grandiflora as the species with the most symmetrical karyotype and Christensonella pachyphylla with the most asymmetrical karyotype. In the cluster analysis, the largest number of species were grouped with the intermediary ideal karyotypes B or C. Considering our results, we recommend the combined use of at least two indexes, especially Ask\% or A1 with Syi, for cytotaxonomic analysis in groups of orchids. In an evolutionary perspective, our results support Stebbins' hypothesis that asymmetric karyotypes derive from a symmetric karyotypes.
\end{abstract}

Keywords: Asymmetry index, karyotype symmetry, chromosome, cytogenetic, evolution.

Received: October 03, 2016; Accepted: December 19, 2016.

\section{Introduction}

The karyotype is the first phenotypic expression of the genotype and provides an overview of the organization of the genetic material in the chromosome (Guerra, 2008). Among the information that can be extracted from karyotypes, i.e. number and morphology of the chromosomes, diversity of heterochromatic bands, gene location, etc., a very peculiar characteristic stands out: the karyotype asymmetry, which is the subject of long debates. Changes in karyotype symmetry often involve modifications in chromosome size and morphology usually caused by DNA sequence expansions or deletions or by centric fusion/fissions (accompanied by disploidy) (Weiss-Schneeweiss and Schneeweiss, 2013).

The search for an index that reflected the karyotype asymmetry started with Lewitsky (1931) and was followed by Huziwara (1962), Arano (1963), Stebbins (1971), and

Send correspondence to Felipe Nollet. Departamento de Ciências Biológicas, Laboratório de Citogenética Vegetal, Centro de Ciências Agrárias, Universidade Federal da Paraíba, Campus II, 58.397-000 Areia, PB, Brazil. E-mail: nolletmedeiros@yahoo.com.br many other authors (for a detailed discussion see Peruzzi and Eroğlu, 2013). For a long time, these indexes were employed by many cytogeneticists and cytotaxonomists to discuss the taxonomic relationships among related species (Dematteis, 1998; D'Emerico et al., 1999; Selvi et al., 2006; Felix et al., 2007; Peruzzi et al., 2009; Souza et al., 2010). Stebbins (1971) suggested that asymmetric karyotypes were originated from symmetrical ones, which has not been properly tested until now.

The existing indexes are separated into two groups: interchromosomal asymmetry indexes, which quantify the heterogeneity in chromosome size, and intrachromosomal asymmetry indexes, which quantify the relative differences in the centromere position among chromosomes of a complement (Stebbins, 1971; Peruzzi and Eroğlu, 2013). Among the interchromosomal asymmetry indexes, $\mathrm{A}_{2}$ (Romero-Zarco, 1986) and $\mathrm{CV}_{\mathrm{CL}}$ (Paszko, 2006) are the most used due to their accuracy in the evaluation of chromosome dissimilarities (Chiarini and Barboza, 2008; Souza et al., 2010; Pierozzi, 2011; Alves et al., 2011; Assis et al., 2013). However, there is no consensus about the best method for calculating the intrachromosomal asymmetry (RomeroZarco, 1986; Peruzzi and Eroğlu, 2013). 
Among the proposed intrachromosomal asymmetry indexes, the following stand out:

The four categories of Stebbins (1971): from A to D according to the proportion of acrocentric and/or telocentric chromosomes in a karyotype, i.e. proportion of chromosomes with a ratio between chromosome arms < $2: 1$. The four categories have subtypes 1 to 3 according to the ratio between the large/small chromosome arms, giving a total of 12 categories (Table 1).

The total form percentage (TF\%; Huziwara, 1962): ratio between the sum of the short arms (p) length and the sum of the total chromosomes length:

\section{$\mathbf{T F} \%=\Sigma \mathrm{p} / \Sigma$ total karyotype length}

The karyotype asymmetry index percentage (Ask\%; Arano, 1963): ratio between the length of the long arms (q) of the chromosome set and the total length of the chromosome set:

\section{Ask $\%=\Sigma q / \Sigma$ total karyotype length}

The symmetric index (Syi; Greilhuber and Speta, 1976): ratio between the average length of the short arms (p) and the average length of the long arms, multiplied by 100:

$$
\text { Syi }=(\Sigma \text { mean of } \mathrm{p} \text { length } / \Sigma \text { mean of q length }) \times 100
$$

The intrachromosomal asymmetry index $A_{1}$ (Romero-Zarco 1986): sum of the ratio between the average length of the short arms in each homologous pairs $\left(b_{i}\right)$ and the average length of the long arms in each homologous pair $\left(B_{i}\right)$ divided by the number of homologous chromosome pairs $(n)$ :

$$
\mathbf{A}_{1}=1-\frac{\sum_{i=1}^{n}\left(b_{i} / B_{i}\right)}{n}
$$

This proposal was later modified by Watanabe et al. (1999), who created the asymmetry index A, and followed by Peruzzi and Eroğlu (2013), who called the same index $\mathrm{M}_{\mathrm{CA}}$. This index results from the sum of the ratio between the differences in the long arm length $\left(B_{i}\right)$ and the short arm length $\left(b_{i}\right)$ of each chromosome and the sum of the lengths of the long and short arms of each chromosome $\left(B_{i}+b_{i}\right)$. The sum is divided by the haploid chromosome number $(n)$ :

$$
\mathbf{A}=\frac{\sum_{i=1}^{n}\left(B_{i}-b_{i} / B_{i}+b_{i}\right)}{n}
$$

The coefficient of variation of the centromeric index $\mathrm{CV}_{\mathrm{CI}}$ (Paszko, 2006): based on the index of interchromosomal asymmetry A2 (standard deviation/total average of the chromosome length):

$$
\mathbf{C V}_{\mathbf{C I}}=\mathrm{A}_{2} \times 100
$$

With so many ways to calculate the intrachromosomal asymmetry, Zuo and Yuan (2011) developed six models of ideal karyotypes to test the accuracy of these methods. These authors observed that the $\mathrm{CV}_{\mathrm{CI}}$ does not reflect the intrachromosomal asymmetry in karyotypes when it is composed by telocentric and/or acrocentric chromosomes. Since the standard deviation decreases in acrocentric or telocentric chromosomes, the $\mathrm{CV}_{\mathrm{CI}}$ is more suitable to indicate the heterogeneity of the centromeric index, i.e. how different is the position of the centromeres among the chromosomes of the complement (see Zuo and Yuan, 2011).

Peruzzi and Eroğlu (2013) discouraged the use of any intrachromosomal asymmetry index for karyotypes with small chromosomes $(\leq 1 \mu \mathrm{m})$, due to the inaccuracy in the arms' measurement. However, the mean chromosome size in plants is $1.5-2.0 \mu \mathrm{m}$. Moreover, if the suggestion of Peruzzi and Eroğlu (2013) is followed, the chromosome symmetry analysis will be prohibitive in a large number of plant species, including a great part of Bromeliaceae, Fabaceae and Orchidaceae species.

Considered one of the most diverse and taxonomically complex plant families among the angiosperms, Orchidaceae comprises 25,971 species with global distribution (Pridgeon et al., 1999; Joppa et al., 2011). The Orchidaceae present a large karyotype variation, with all types of chromosome morphology distributed in species with chromosome numbers varying from $2 n=12$ in Erycina pusilla (L.) N.H.Williams \& M.W.Chase (Felix and Guerra, 1999) to $2 n=240$ in Epidendrum cinnabarinum Salzm. ex Lindl. (Guerra, 2000; Felix and Guerra, 2010; Assis et al., 2013). Except for the subfamily Cypripedioideae, Orchidaceae species are characterized by small chromosomes (Larsen, 1968; Okada, 1988).

Table 1 - Intrachromosomal asymmetry indexes. The total of 12 indexes is composted of the four categories of Stebbins (1971) - A to D according to the proportion of acrocentric and/or telocentric chromosomes in a karyotype - and subtypes 1 to 3 according to the ratio between the large/small chromosome arms in each of these.

\begin{tabular}{lccr}
\hline Ratio: largest/smallest chromosomes & & Proportion of chromosomes with arm ratio $<2: 1$ \\
\cline { 2 - 4 } & 0.0 & $0.01-0.5$ & $0.51-0.99$ \\
\hline$<: 1$ & $1 \mathrm{~A}$ & $1 \mathrm{~B}$ & $1 \mathrm{C}$ \\
$2: 1-4: 1$ & $2 \mathrm{~A}$ & $2 \mathrm{~B}$ & $2 \mathrm{C}$ \\
$>4: 1$ & $3 \mathrm{~A}$ & $3 \mathrm{~B}$ & $3 \mathrm{C}$ \\
\hline
\end{tabular}


The wide karyotype diversity observed in Orchidaceae makes this plant family an excellent group for evaluating the applicability of karyotype asymmetry indexes, especially the intrachromosomal index. Thus, the present study aimed to compare different intrachromosomal asymmetry indexes, in order to indicate the most efficient for the estimation of karyotype asymmetry in orchids, including species with small chromosomes. Besides, we aimed to compare our results with the Orchidaceae phylogenetic proposal to test the hypothesis of Stebbins (1971) that asymmetric karyotypes derived from symmetric ones.

\section{Material and Methods}

\section{Chromosome measurements}

A literature search was performed to select informative photographic records of metaphases quality - clear identification of centromere and secondary constrictions and the available voucher (Table 2 ).

The arm ratio ( $r=$ length of the long arm/length of the short arm) was used to classify the chromosomes as metacentric (M: $\mathrm{r}=1.00$ to 1.49$)$, submetacentric $(\mathrm{S}: \mathrm{r}=$ 1.50 to 2.99$)$, acrocentric $(\mathrm{A}: \mathrm{r} \geq 3.00)$ and telocentric $(\mathrm{T}: \mathrm{r}$ $=\infty$ ), according to Guerra (1986). We did not consider differences between acrocentric and telocentric chromosomes. For chromosome measurements we used Imagetool ${ }^{\circledR}$ $\begin{array}{llll}\text { software } & \text { version } & 3.0 & \text { (available at }\end{array}$ http://compdent.uthscsa.edu/dig/itdesc.html) calibrated with scales available on the selected images.

The interchromosomal asymmetry was calculated using $\mathrm{A}_{2}$ by Romero-Zarco (1986). Five different indexes were estimated for the intrachromosomal asymmetry: TF\% (Huziwara, 1962); Ask\% (Arano, 1963); Syi (Greihuber and Speta, 1976); A (Romero-Zarco, 1986); and A (Watanabe et al., 1999). In addition, the ideal karyotypes (Zuo and Yuan, 2011) were used to establish a comparative standard for the analyzed karyotypes. The ideal karyotypes, ranked from $\mathrm{A}$ to $\mathrm{F}$, present chromosome morphology based on Levan et al. (1964). However, here we followed the nomenclature proposed by Guerra (1986) based on the percentage of acrocentric/telocentric chromosomes: (1) up to $30 \%$ (slightly asymmetric - SA); (2) from 31 to $50 \%$ (moderately asymmetric - MA) and (3) more than 50\% (strongly asymmetric - StA).

\section{Cluster analysis}

The intrachromosomal index values were separately used for cluster analysis. The obtained values were categorized and used to define the limits of each category (Table $\mathrm{S} 1)$. For the cluster analysis we used the UPGMA algorithm (unweighted pair-group method with arithmetic means) implemented in the software Mesquite ${ }^{\mathbb{R}}$ (Maddison and Maddison, 2015). Ten trees were generated for each index using the distances from the data matrix by majority consensus. Subsequently, only one consensus tree was stored. The software Dendroscope ${ }^{\circledR}$ (Huson and Scornavacca, 2012) was used to root the tree with the most ideal symmetrical karyotype (karyotype A) as an outgroup, following the hypothesis of Stebbins (1971).

\section{Statistical analysis}

To test the hypothesis of Stebbins (1971), the mean values of the interchromosomal index A2 and the intrachromosomal asymmetry indexes were separately used, in order to compare the karyotype asymmetry levels for each subfamily. The variation between the mean values of asymmetry indexes for the subfamilies was compared statistically by ANOVA followed by Tukey's test using BioEstat v.5.3 (Ayres et al., 2007).

\section{Results}

\section{Karyomorphometric analysis}

The metaphases of 64 species, distributed throughout four subfamilies (Cypripedoideae, Epidendroideae, Orchidoideae and Vanilloideae) were selected across 16 references (Table 2). No karyotype analysis was found for Apostasioideae. Chromosome numbers ranged from $2 n=$ 12 in Erycina pusilla (Epidendroideae) to $2 n=56$ in Eurystyles actinosophila (Barb. Rodr.) Schltr (Orchidoideae). The Campylocentrum neglectum (Rchb.f. \& Warm.) Cogn. (Epidendroideae) presented the smallest chromosomes, ranging from $0.62 \mu \mathrm{m}$ to $1.20 \mu \mathrm{m}$, while Paphiopedilum randsii Fowlie (Cypripedioideae) presented the largest chromosomes, ranging from $10.74 \mu \mathrm{m}$ to $22.48 \mu \mathrm{m}$ (Table 2). The total sum of haploid chromosome length (hcl) ranged from $27.78 \mu \mathrm{m}$ in Pabstiella fusca (Lind1.) Chiron \& Xim.Bols. (Epidendroideae) to 395.88 $\mu \mathrm{m}$ in Paphiopedilum dianthum Tang \& F.T.Wang (Cypripedioideae) (Table 2).

Regarding interchromosomal asymmetry $\left(\mathrm{A}_{2}\right)$, the most symmetric karyotype was found in Christensonella pumila (Hook.) Szlach. $\left(\mathrm{A}_{2}=0.12\right)$, while the most asymmetrical were found in Cephalanthera damasonium (Mill.) Druce and Pteroglossa lurida (M.N.Correa) Garay $\left(\mathrm{A}_{2}=\right.$ 0.60 ; see Table 2). However, when comparing the subfamilies, the statistical test failed to show any difference $(\mathrm{F}=$ $1.6526, \mathrm{p}=0.1988$; Figure 1).

The five tested intrachromosomal asymmetry indexes provided the same result: the most symmetric karyotype was found in Sarcoglottis grandiflora (Hook.) Klotzsch $(44 \mathrm{M}+2 \mathrm{~S}$; see bold numbers in Table 2$)$ and the most asymmetric karyotype was found in Christensonella pachyphylla (Schltr. ex Hoehne) Szlach., (20S + 18A; see underlined numbers in Table 2). 


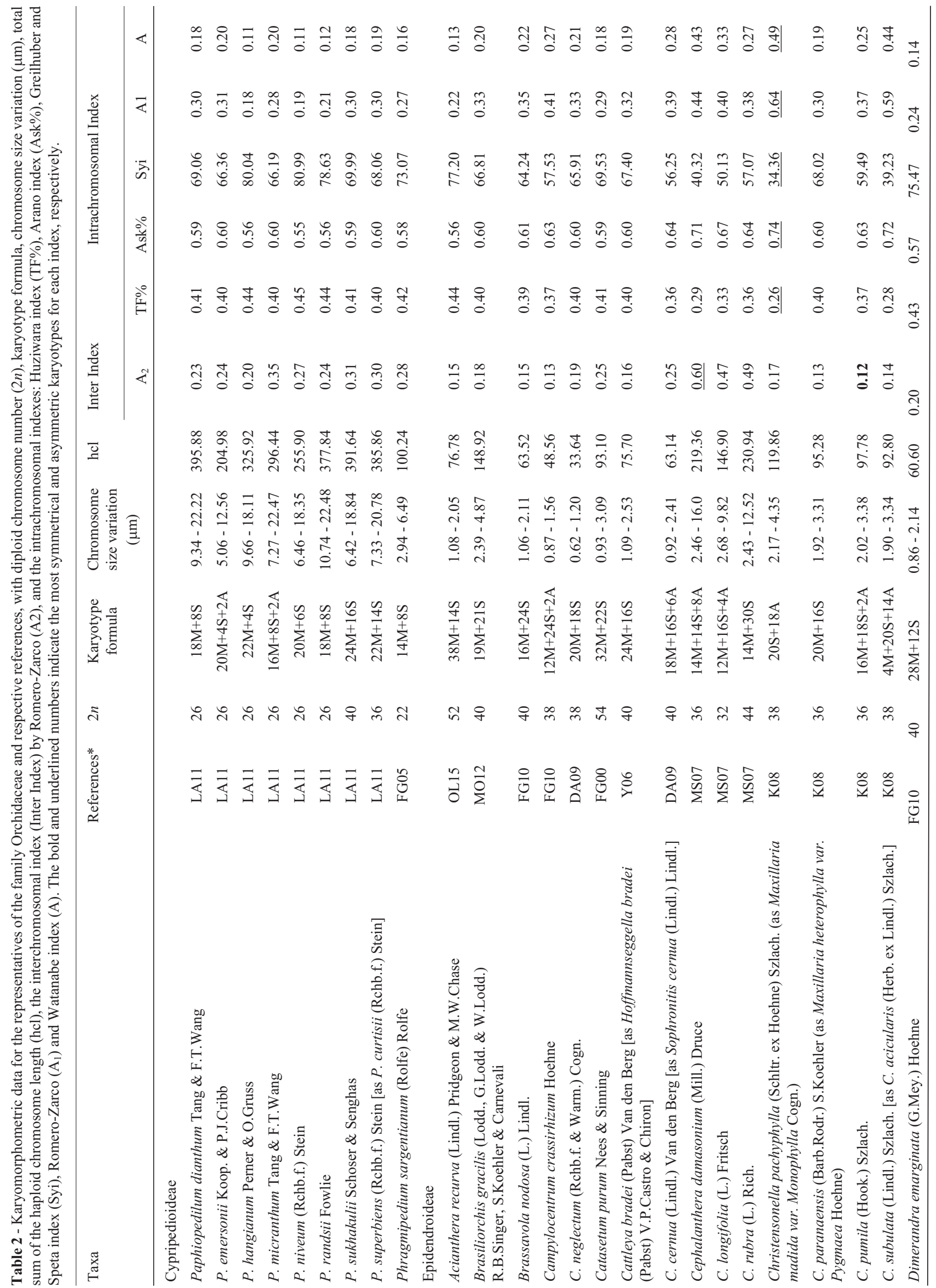




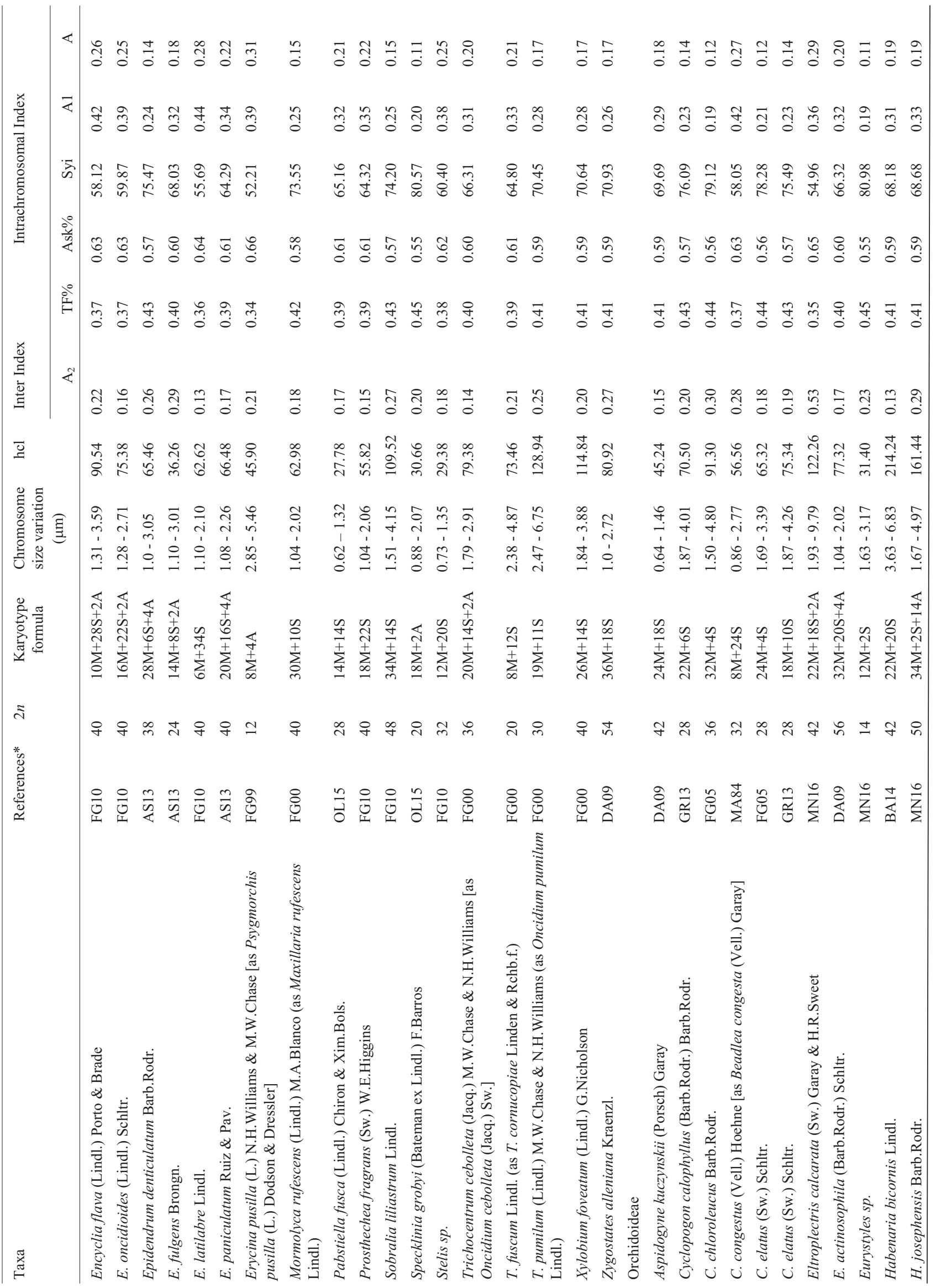




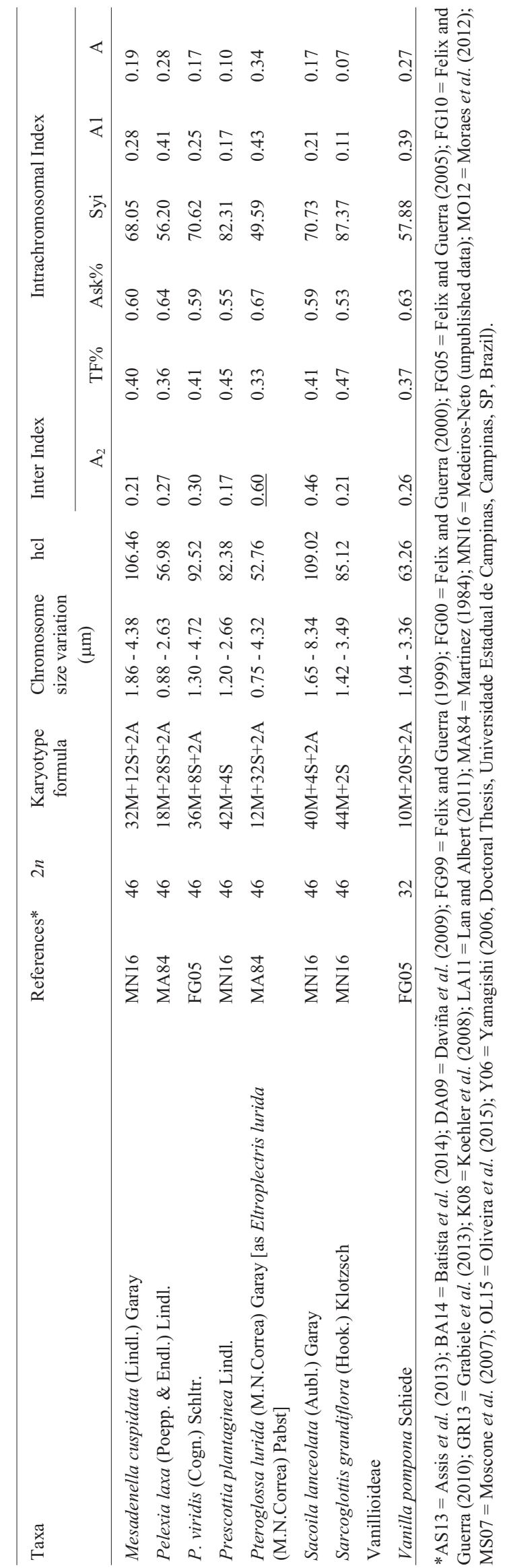

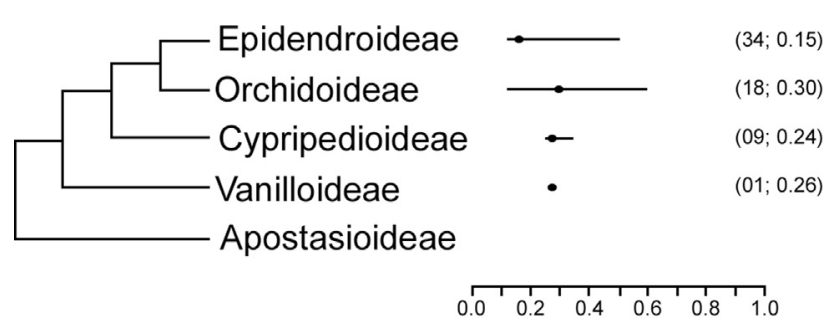

Figure 1 - Interchromosomal index A2 values for Orchidaceae subfamily. For each subfamily the mean value (dot), the amplitude of variation (bar), the number of species analyzed and mode value (last two data in the parenthesis, respectively) are presented.

\section{Cluster analysis for intrachromosomal indexes}

Cluster analysis using the values found for $\mathrm{TF} \%$ grouped most species with the ideal karyotype $\mathrm{C}$, the Sarcoglottis grandiflora with the ideal karyotype B and Christensonella pachyphylla with the ideal karyotype D (Figure $\mathrm{S} 1$ ). Ask $\%$ and $\mathrm{A}_{1}$ indexes presented identical trees (Figure S2) in the cluster analysis, with most species grouped with ideal karyotype B, plus a clade, separated into two groups: (1) a polytomy with the ideal karyotypes D, E and $\mathrm{F}$ and (2) a group with Christensonella pachyphylla, $C$. subulata (Lindl.) Szlach. and the ideal karyotype C. The cluster analysis for A and Syi also formed identical trees (Figure S3), similar to trees obtained with Ask\% and A1 (Figure S2). A difference was found with Christensonella subulata, which was grouped with most species and the ideal karyotype B (instead of C). The indexes Ask \% and A1 (Figure S2), and Syi and A (Figure S3) grouped Sarcoglottis grandiflora as a sister group of karyotype A. The indexes Ask\%, A1, Syi and A provided more consistent groups (Figure 2), reflecting the species karyotype composition in the ideal karyotypes, as proposed by Zuo and Yuan (2011).

Comparing the four most congruent intrachromosomal indexes, Ask\%, A1, Syi and A, with the current proposed Orchidaceae phylogeny (Chase et al., 2015), all indexes presented similar mean and mode values for Orchidoideae and Cypripedioideae (Figure 3). Index A did not detected a difference among subfamilies, after Tuckey's test (despite the $F=4.1420, p=0.0203$ ). The indexes Ask\% and Syi indicated that karyotypes from Epidendroideae and Orchidoideae are more asymmetrical than Cypripedioideae - the most basal subfamily among the three $(\mathrm{F}=4.4915$ and 4.7008 , respectively; $\mathrm{p}=0.01$ for both indexes). The A1 index suggested Epidendroideae as the most asymmetric karyotype among subfamilies $(\mathrm{F}=$ $5.77, \mathrm{p}=0.0054)$.

\section{Discussion}

The inter and intrachromosomal asymmetry values observed here corroborate previous studies, with a slight variation for some species, such as Epidendrum 

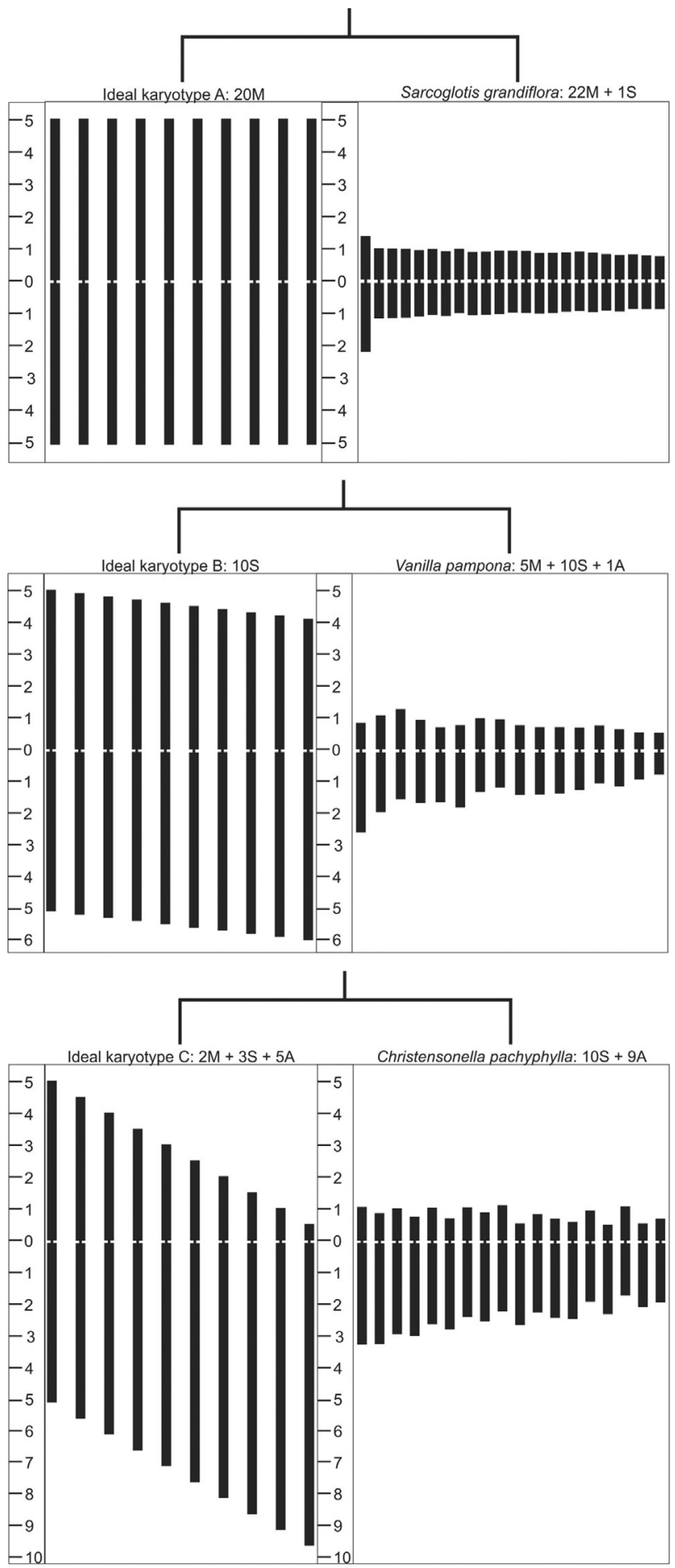

Figure 2 - Ideograms of the ideal karyotypes A, B and C, as well as the most similar species, grouped by UPGMA, equally obtained by the indexes Ask \%, A1, Syi and A. The numeric scale at the right side of the ideogram is given in micrometers $(\mu \mathrm{m})$.

paniculatum Ruiz \& Pav., E. fulgens Brongn. (Assis et al., 2013), Cyclopogon calophyllus (Barb.Rodr.) Barb.Rodr. and C. elatus (Sw.) Schltr. (Grabiele et al., 2013). Therefore, we can observe that the relationship between the two

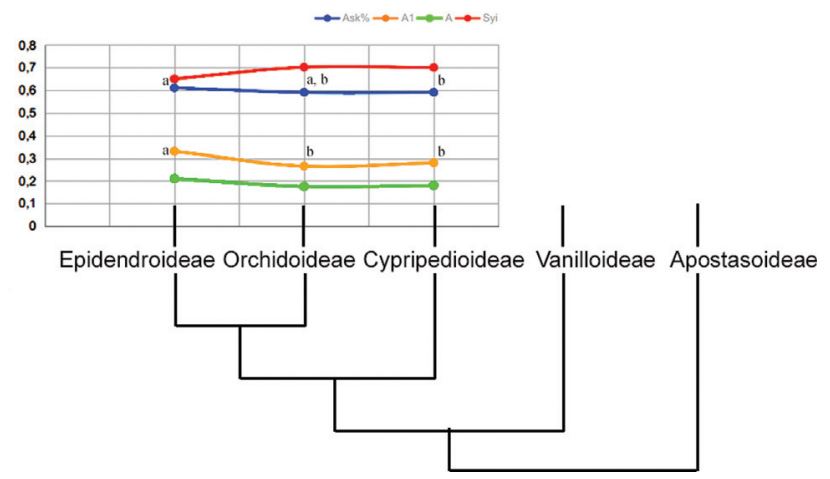

Figure 3 - Intrachromosomal asymmetry values obtained by Ask\% (blue), A1 (red), A (green) and Syi (orange) indexes for the Orchidaceae subfamily. The numeric scale at the right side indicates the mean value for the four intrachromosomal indexes. The Syi value was divided by 100 . Subfamilies indicated by the same letters are not significantly different (Tukey test, $\mathrm{p}<0.05$ ).

kinds of asymmetry (intra and interchromosomal) is not always unidirectional, but it is a result of complex rearrangements that modify both the centromere position and the chromosome size in a karyotype.

\section{The interchromosomal index}

The $\mathrm{A}_{2}$ index employed here yielded values close to zero for some species, mainly in the subfamilies Epidendroideae and Orchidoideae. In such cases, the index reflects a conservation among chromosome size in the karyotype; other species, however, presented high $\mathrm{A}_{2}$ values.

The highly asymmetric karyotypes could be the result of chromosome rearrangements, what could also cause bimodality, as observed in Cephalanthera damasonium (Epidendroideae; Moscone et al., 2007) and Pteroglossa lurida (Orchidoideae; Martinez 1984), both with $\mathrm{A}_{2}=0.60$. The origin of bimodal karyotypes could be due to the loss of chromosome segments after polyploidy, resulting in the formation of smaller chromosomes (Weiss-Schneeweiss and Schneeweiss, 2013), or due to unequal translocations (Stebbins, 1971), differential amplification of heterochromatic regions (de la Herrán et al., 2001), or even in the hybridization between species with different chromosome sizes. All these events increase the interchromosomal asymmetry by increasing the morphological discontinuities between chromosomes in a karyotype.

\section{The intrachromosomal indexes}

Regarding the intrachromosomal asymmetry, we showed that Orchidaceae karyotypes ranged from slightly asymmetric to moderately asymmetric. The intrachromosomal asymmetry is defined by the presence of a greater number of acrocentric/telocentric chromosomes in relation to the metacentric and submetacentric ones, a consequence of changes in centromere position (Stebbins, 1971) - in which case the chromosome rearrangement could affect all 
chromosomes in the same way and even increase the karyotype asymmetry. Therefore, the efficacy of the intrachromosomal asymmetry indexes is dependent on the precise identification of the centromere and a well-defined chromosome morphology, and not on chromosome size. The indexes $\mathrm{Ask} \%$ and $\mathrm{A}_{1}$ proved to be more useful in determining the intrachromosomal asymmetry, even in species with small chromosomes, like Campylocentrum neglectum.

The extreme symmetry (ideal karyotype A) or the extreme asymmetry (ideal karyotype F) karyotypes are hardly found in nature. However, in the present analysis, an extreme of symmetric karyotype was found in Sarcoglottis grandiflora, grouped with the ideal karyotype A. Christensonella pachyphylla showed the most asymmetric karyotype, but this species was grouped with ideal karyotypes $\mathrm{C}$ and $\mathrm{D}$ and not with the extreme ideal karyotype $\mathrm{F}$.

The occurrence of asymmetric karyotypes is probably a consequence of chromosomal structural changes, especially centric fusion/fission, a very common rearrangement in Orchidaceae (Pinheiro et al., 2009; Yamagishi-Costa and Forni-Martins, 2009; Assis et al., 2013; Moraes et al., 2012, 2013; 2016). Christensonella Szlach. presents a dysploidy variation $(2 n=36$ and 38$)$ and the occurrence of centric fusion/fission is suggested as the main cause. This is illustrated by the double DAPI ${ }^{+}$band holding the centromere in C. fernandiana, as the remainder species present just one DAPI ${ }^{+}$band (Koehler et al., 2008; Moraes et al., 2012). The centric fusion/fission is suggested to be the cause of the frequent dysploidy in other genera in subtribe Maxillariinae (Moraes et al., 2012; 2016) and Orchidaceae (Pinheiro et al., 2009; Felix and Guerra, 2010; Assis et al., 2013). The same can be detected in other plant groups as the genus Tristagma Poepp. (as Ipheion Raf., Souza et al., 2010): Tristagma tweedieanum (Baker) Traub $(2 n=14$, karyotypic formula $14 \mathrm{~A}, \mathrm{~A}_{1}=0.86$ ) and $T$. uniflorum (Lindl.) Traub $(2 n=12$, karyotypic formula $=2 \mathrm{SM}+10 \mathrm{~A}$, $\mathrm{A}_{1}=0.78$ ), family Iridaceae (Goldblatt, 1990; Alves et al., 2011; Moraes et al., 2015), Asteraceae (Brachyscome Cass.; Watanabe et al., 1999) and Sapindaceae (Serjania Mill.; Coulleri et al., 2012).

\section{The Stebbins' hypothesis}

The relationship between karyotype asymmetry and species evolution could be discussed based on intrachromosomal indexes, since the interchromosomal index does not differ among subfamilies. The intrachromosomal asymmetry indexes indicated the karyotypes of some representatives of the subfamily Epidendroideae as the most asymmetric - in agreement with the hypothesis of Stebbins (1971) that asymmetric karyotypes had been originated from symmetrical ones. Based on the statistical results and cluster analysis the congruent indexes Ask\%, A1 and Syi indicated Epidendroideae as the most derivate subfamily, presenting the most asymmetrical karyotype, while the rep- resentatives of the subfamily Cypripedioideae have more symmetrical karyotypes.

\section{Conclusions}

Considering our results, the indexes Ask\% (Arano, 1963), $A_{1}$ (Romero-Zarco, 1986) and Syi are recommended for the estimation of intrachromosomal asymmetry in cytotaxonomic studies, especially in a combined fashion. We showed that the critical point for the efficacy of an asymmetric index is the well-preserved chromosome morphology and precise definition of the centromere position - and not the size of chromosomes. Moreover, the higher karyotype asymmetry associated with the derivative subfamily Epidendroideae supports Stebbins' hypothesis that asymmetric karyotypes tend to derive from symmetric karyotypes.

\section{Acknowledgments}

The authors thank the Conselho Nacional de Desenvolvimento Científico e Tecnológico (CNPq Proc. 400209/2014-4 and Proc. 460990/2014-4), Coordenação de Aperfeiçoamento de Pessoal de Nível Superior (Capes) and Fundação de Apoio à Pesquisa de São Paulo (FAPESP 2011/22215-3) for financial support and research grants, and Instituto Nacional do Semiárido (INSA) for technical support.

\section{References}

Ayres M, Ayres Jr M, Ayres DL and Santos AA (2007) BioEstat Aplicações estatísticas nas áreas das ciências bio-médicas, version 5.3. Instituto de Desenvolvimento Sustentável Mamirauá, Tefé, Brazil.

Alves LIF, Lima SAA and Felix LP (2011) Chromosome characterization and variability in some Iridaceae from Northeastern Brazil. Genet Mol Biol 34:259-267.

Arano H (1963) Cytological studies in subfamily Carduoideae (Compositae) of Japan. IX. The karyotype analysis and phylogenic consideration of Pertya and Ainsliaea. Bot Mag 76:32-39.

Assis FNM, Souza BCQ, Medeiros-Neto E, Pinheiro F, Silva AEB and Felix LP (2013) Karyology of the genus Epidendrum (Orchidaceae: Laeliinae) with emphasis on subgenus Amphiglottium and chromosome number variability in Epidendrum secundum. Bot J Linn Soc 172:329-344.

Batista JAN, Proite K, Carvalho BM, Vale AA and Felix LP (2014) From Cuba to most of the Neotropic: Habenaria bicornis (Orchidaceae) is widespread from Mexico to southeastern Brazil. Lankesteriana 13:165-184.

Chase MW, Cameron KM, Freudenstein JV, Pridgeon AM, Salazar G, van den Berg C and Schuiteman A (2015) An updated classification of Orchidaceae. Bot J Linn Soc 177:151-174.

Chiarini FE and Barboza GE (2008) Karyological studies in Jaborosa (Solanaceae). Bot J Lin Soc 156:467-478.

Coulleri JP, Dematteis M and Ferrucci MS (2012) A new insight into Serjania Mill. (Sapindaceae, Paullinieae) infrageneric classification: A cytogenetic approach. Plant Syst Evol 298:1743-1753. 
D’Emerico S, Grünanger P, Scrugli A and Pignone D (1999) Karyomorphological parameters and C-bands distribution suggest phyletic relationship within the subtribe Limodorinae Bentham (Orchidaceae). Plant Syst Evol 217:147161.

Daviña JR, Grabiele M, Cerutti JC, Hojsgaard DH, Almada RD, Insaurralde IS and Honfi AI (2009) Chromosome studies in Orchidaceae from Argentina. Genet Mol Biol 32:811-821.

de la Herrán R, Robles F, Cuñado N, Santos JL, Ruiz-Rejón M, Garrido-Ramos MA and Réjon CR (2001) A heterochromatic satellite DNA is highly amplified in a single chromosome of Muscari (Hyacinthaceae). Chromosoma 110:197202.

Dematteis M (1998) Karyotype analysis in some Vernonia species (Asteraceae) from South America. Caryologia 51:279-288.

Felix LP and Guerra M (1999) Chromosome analysis in Psygmorchis pusilla (L.) Dodson et Dressler: The smallest chromosome number known in Orchidaceae. Caryologia 52:165-168.

Felix LP and Guerra M (2000) Cytogenetics and cytotaxonomy of some Brazilian species of Cymbidioid orchids. Genet Mol Biol 23:957-978.

Felix LP and Guerra M (2005) Basic chromosome numbers of terrestrial orchids. Plant Syst Evol 254:131-148.

Felix LP and Guerra M (2010) Variation in chromosome number and the basic number of subfamily Epidendroideae (Orchidaceae). Bot J Linn Soc 163:234-278.

Felix WJP, Almeida A, de Melo NF and Felix LP (2007) Citogenética de duas espécies de Zephyranthes herb (Amaryllidaceae-Hipeastreae) cultivadas. Rev Bras Biocienc 5:294-296.

Goldblatt P (1990) Phylogeny and classification of Iridaceae. Ann Missouri Bot Gard 77:607-627.

Grabiele M, Cerutti JC, Hojsgaard DH, Almada RD, Daviña JR and Honfi AI (2013) Comparative cytogenetics in Cyclopogon (Orchidaceae). Biologia 68:48-54.

Greilhuber J and Speta F (1976) C-banded karyotypes in the Scilla hohenackeri group, S. persica, and Puschkinia (Liliaceae). Plant Syst Evol 126:149-188.

Guerra M (1986) Reviewing chromosome nomenclature of Levan et al. Rev Bras Gen 4:741-743.

Guerra M (2000) Patterns of heterochromatin distribution in plant chromosomes. Genet Mol Biol 23:1029-1041.

Guerra M (2008) Chromosome numbers in plant cytotaxonomy: Concepts and implications. Cytogenet Genome Res 120:339-350.

Huson DH and Scornavacca C (2012) Dendroscope 3: An interactive tool for rooted phylogenetic trees and networks. Syst Biol 61:1061-1067.

Huziwara Y (1962) Karyotype analysis in some genera of Compositae. VIII. Further studies on the chromosome of Aster. Amer J Bot 49:116-119.

Joppa LN, Roberts DL and Pimm SL (2011) How many species of flowering plants are there? Proc R Soc Lond B Biol Sci 278:554-559.

Koehler S, Cabral JS, Whitten WM, Williams NH, Singer RB, Neubig KM, Guerra M, Souza AP and Amaral MCE (2008) Molecular phylogeny of the Neotropical genus Christensonella (Orchidaceae, Maxillariinae): Species delimitation and insights into chromosome evolution. Ann Bot 102:491-507.
Lan T and Albert VA (2011) Dynamic distribution patterns of ribosomal DNA and chromosomal evolution in Paphiopedilum, a lady's slipper orchid. BMC Plant Biol 11:126.

Larsen K (1968) Brief notes on Neuwiedia singapureana in Thailand. Nat Hist Bull Siam Soc 22:330-331.

Levan A, Fredgra K and Sandberg AA (1964) Nomenclature for centromeric position on chromosomes. Hereditas 52:201220.

Lewitsky GA (1931) An essay on cytological analysis of the fixing action of the chromacetic formalin and the chromic formalin. Bull Appl Bot Genet Plant Breed 27:187-240.

Martinez A (1984) The chromosomes of orchids, vol. 3, Spiranthinae and Cranichidinae. Kew Bulletin 40:139-147.

Moraes AP, Leitch IJ and Leitch AR (2012) Chromosome studies in Orchidaceae: Karyotype divergence in Neotropical genera in subtribe Maxillariinae. Bot J Linn Soc 170:29-39.

Moraes AP, Chinaglia M, Palma-Silva C and Pinheiro F (2013) Interploidy hybridization in sympatric zones: The formation of Epidendrum fulgens $\times$ E. puniceoluteum hybrids (Epidendroideae, Orchidaceae). Ecol Evol 3:3824-3837.

Moraes AP, Souza-Chies TT, Stiehl-Alves EM, Piccolli P, Eggers L, Yakolev SS, Brown SC, Chaveau O, Nador S, Bourge M, et al. (2015) Evolutionary trends in Iridaceae: New cytogenetic findings from the New World. Bot J Linn Soc 177:27-49.

Moraes AP, Simões AO, Alayon DIO, Barros F and Forni-Martins ER (2016) Detecting mechanisms of karyotype evolution in Heterotaxis (Orchidaceae). PLoS One 11:e0165960.

Moscone EA, Samuel R, Schwarzacher T, Schweizer D and Pedrosa-Harand A (2007) Complex rearrangements are involved in Cephalanthera (Orchidaceae) chromosome evolution. Chromosome Res 15:931-943.

Okada H (1988) Karyomorphological observations of Apostasia nuda and Neuwiedia veratrifolia (Apostasiaceae, Orchidaceae). Jpn J Bot 63:16-22.

Oliveira IG, Moraes AP, Almeida EM, Assis FNM, Barros F and Felix LP (2015) Chromosomal evolution in Pleurothallidinae (Orchidaceae: Epidendroideae) with emphasis on the genus Acianthera: Chromosome numbers and heterochromatin. Bot J Linn Soc 178:102-120.

Paszko B (2006) A critical review and a new proposal of karyotype asymmetry indices. Plant Syst Evol 258:39-48.

Peruzzi L and Eroğlu HE (2013) Karyotype asymmetry: Again, how to measure and what to measure? Comp Cytogenet 7:1-9.

Peruzzi L, Leitch IJ and Caparelli KF (2009) Chromosome diversity and evolution in Liliaceae. Ann Bot 103:459-475.

Pierozzi NI (2011) Karyotype and NOR-banding of mitotic chromosomes of some Vitis L. species. Rev Bras Frutic 33:564570.

Pinheiro F, Koehler S, Corrêa AM, Salatino MLF, Salatino A and Barros F (2009) Phylogenetic relationships and infrageneric classification of Epidendrum subgenus Amphiglottium (Laeliinae, Orchidaceae). Plant Syst Evol 283:165-177.

Pridgeon AM, Cribb PJ, Chase MW and Rasmussen F (1999) Genera Orchidacearum, vol.1. Oxford University Press, Oxford, $240 \mathrm{p}$.

Romero-Zarco C (1986) A new method for estimating karyotype asymmetry. Taxon 35:526. 
Selvi F, Coppi A and Bigazzi M (2006) Karyotype variation, evolution and phylogeny in Borago (Boraginaceae), with emphasis on subgenus Buglossites in the Corso-Sardinian system. Ann Bot 98:857-868.

Souza LGR, Crosa O and Guerra M (2010) Karyological circumscription of Ipheion Rafinesque (Gilliesioideae, Alliaceae). Plant Syst Evol 287:119-127.

Stebbins GL (1971) Chromosomal Evolution in Higher Plants. Edward Arnold Ltd, London, 216 p.

Watanabe K, Yahara T, Denda T and Kosuge K (1999) Chromosomal evolution in the genus Brachyscome (Asteraceae, Astereae): Statistical tests regarding correlation between changes in karyotype and habit using phylogenetic information. J Plant Res 112:145-161.

Weiss-Schneeweiss H and Schneeweiss G (2013) Karyotype diversity and evolutionary trends in Angiosperms. In: Greilhuber J, Dolezel J and Wendel JF (eds) Plant Genome Diversity vol. 2. Springer, Vienna, pp 209-230.

Yamagishi-Costa J and Forni-Martins E (2009) Hybridization and polyploidy: Cytogenetic indications for Hoffmannseggella (Orchidaceae) species evolution. Int J Bot 5:93-99.

Zuo L and Yuan Q (2011) The difference between the heterogeneity of the centromeric index and intrachromosomal asymmetry. Plant Syst Evol 297:141-145.

\section{Internet Resources}

Maddison WP and Maddison DR (2015) Mesquite: A modular system for evolutionary analysis. Version 3.02, http://mesquiteproject.org (April 10, 2016).

\section{Supplementary Material}

The following online material is available for this article: Table S1 - Asymmetry values for ideal karyotypes.

Figure S1 - UPGMA analysis using the intrachromosomal asymmetry values from $\mathrm{TF} \%$ index.

Figure S2 - UPGMA analysis using the intrachromosomal asymmetry values from $\mathrm{Ask} \%$ and $\mathrm{A}_{1}$ indexes.

Figure S3 - UPGMA analysis using the intrachromosomal asymmetry values from Syi and A indexes.

Associate Editor: Marcelo Guerra

License information: This is an open-access article distributed under the terms of the Creative Commons Attribution License (type CC-BY), which permits unrestricted use, distribution and reproduction in any medium, provided the original article is properly cited. 